\begin{tabular}{ccc}
\hline International Journal of Engineering \& Technology, $7(4.3)(2018) 524-529$ \\
SPC & Website: www.sciencepubco.com/index.php/IJET \\
Research paper & Technology \\
\hline
\end{tabular}

\title{
The Impact of Corporate Sector on Social Standards Development in Ukraine
}

\author{
Viktoriia Tretyak $^{1}$, Anton Kvitka ${ }^{1}$, Kateryna Andreieva ${ }^{1 *}$, Maksym Bieliai $^{1}$ \\ ${ }^{1}$ V.N. Karazin Kharkiv National University \\ *Corresponding author E-mail: andreeva@karazin.ua
}

\begin{abstract}
This paper is devoted to determining the impact of the corporate sector on the development and implementation of social standards in the society in which it operates. Attention is paid to the formation of trends in social standards changes in terms of the activities of industrial corporations. By studying a number of indicators, a comparative analysis of these processes in Ukraine and Europe is presented. Recommendations for domestic industrial companies have been worked out, implementation of which will significantly improve the competitiveness of Ukrainian corporate sector and determine the tendencies of harmonization of social standards in Ukraine with the European ones.
\end{abstract}

Keywords: Corporate sector; corporate social responsibility; corporations; social development; social standards.

\section{Introduction}

The share of the corporate sector in the total number of enterprises in the world is increasing every year, and corporations are able to exert a comprehensive influence on economic and social processes in the countries. The definition of the relationship between the corporate sector and the mentality, the processes of establishing social standards as declarative (benefits, labor protection, insurance, awards, aids, etc.) and social norms and rules of conduct of people is important for the further development of corporate business forms.

The relevance of studying this issue is determined by many factors, the most significant of which are presented in Figure 1.

The European integration vector of the Ukrainian economy creates the need to find effective ways to involve the corporations in solving social problems

Trend-forming role of the corporate sector in the Ukrainian economy

The development of the Ukrainian corporate sector is one of the priorities of the government in accordance with the Strategy of Sustainable Development of Ukraine until 2030 and the medium-term plan of the Government's priority actions by 2020 ;

Limited resources to ensure social standards

Fig. 1: Factors determining the relevance of the study.

\section{Main Results}

Wan Fauziah and Idris Adamu [1] in one of their studies put forward the hypothesis that the corporate sector is a trend-forming system, which means that corporations reactions to different phenomena and processes can be extrapolated to the reaction of the society in which they operate.

However, the use of this statement as a true one is impossible and requires confirmation or refutation. For this the decision was made to conduct a correlation analysis between the complex indices: World Corporate Governance Index (WCGI) and Social Progress Index (SPI). Their structure and organizations that calculate these indicators are presented in Figure 2.

Each of these indices is complex and includes a set of different indicators (measurements, statistical data, survey results, etc.). The source data for their calculation and the organizations calculating them are different. The possibility of false correlation can be excluded due to the same or related source data.

Based on the data of these indices (in 2017), a correlation analysis was carried out and a dependence with the value $R^{2}{ }_{2017}=0.8452$ was found demonstrating a high level of correlation. The calculations take into account data from 128 countries with crossreference values for 2017 and 2016 in both indices. 


\begin{tabular}{|c|c|}
\hline Social Progress Index & World Corporate Governance Index \\
\hline Basic human needs & Corporate governance structure \\
\hline Welfare & Corporate Governance Code \\
\hline Possibility of self-realization & Social Responsibility \\
\hline Nutrition and medical care & Corporate corruption \\
\hline Water and sanitation & Corporative legal corruption \\
\hline Shelter & Fostering Corruption \\
\hline Personal security & Corporate ethics \\
\hline Access to basic knowledge & Public sector ethics \\
\hline Access to information and & Judicial / legal efficiency \\
\hline communications & Activities of stock exchanges \\
\hline Health and wellness & Capital market control \\
\hline Ecology & Influence of NGOs on corporation \\
\hline Personal rights & \\
\hline Personal freedom and choice & \\
\hline Tolerance and inclusion & \\
\hline Access to higher education & \\
\hline
\end{tabular}

«Social progress imperative»

«SAHA Ratings»

Fig. 2: World Corporate Governance Index (WCGI) And Social Progress Index (SPI) `s structure. [2, 3, 4, 5]

Table 1: Top 19 countries for the Social Progress Index with corresponding WCGI values in 2017 [3,5]

\begin{tabular}{|c|l|l|l|}
\hline № & \multicolumn{1}{|c|}{ Country } & Mark of the SPI & Group at WCGI \\
\hline 1 & Denmark & 90.57 & Group 1 \\
\hline 2 & Finland & 90.53 & Group 1 \\
\hline 3 & Norway & 90.27 & Group 1 \\
\hline 4 & Iceland & 90.27 & Group 2 \\
\hline 5 & Switzerland & 90.10 & Group 1 \\
\hline 6 & Canada & 89.84 & Group 1 \\
\hline 7 & Netherlands & 89.82 & Group 2 \\
\hline 8 & Sweden & 89.66 & Group 1 \\
\hline 9 & Australia & 89.30 & Group 1 \\
\hline 10 & New Zealand & 89.30 & Group 2 \\
\hline 11 & Ireland & 88.91 & Group 2 \\
\hline 12 & UK & 88.73 & Group 1 \\
\hline 13 & Germany & 88.50 & Group 1 \\
\hline 14 & Austria & 87.98 & Group 1 \\
\hline 15 & Belgium & 87.15 & Group 1 \\
\hline 16 & Spain & 86.96 & Group 2 \\
\hline 17 & Japan & 86.44 & Group 1 \\
\hline 18 & the United States & 86.43 & Group 1 \\
\hline 19 & France & 85.92 & Group 1 \\
\hline
\end{tabular}

Among the 19 countries that are at the top of the social progress rating, 14 belong to the first group under the World Corporate Governance index, and five to the second group (Table 1). It should be noted that in general the index was calculated for 150 countries, which were divided into 5 main groups, where the first group has the highest scores (80-100), and group 5 has the lowest (0-20).

To analyse the systemic nature of this dependence, similar calculations were made based on 2016 data with a similar sample (128 countries with cross-reference values for 2017 and 2016 in both indices). The value $\mathrm{R}_{2016}^{2}$ is 0.8278 , which, as in the previous case, corresponds to a high level of correlation. The deviation between $\mathrm{R}_{2016}^{2}$ and $\mathrm{R}_{2017}^{2}$ is $2 \%$, which indicates a very high degree of systemic correlational dependence.

Among the 19 countries that were at the top of the social progress rating in 2016, 12 are in the first group under the World Corporate Governance index, and seven are in the second group close to similar calculations in 2017 (Table 2).
Table 2: Top 19 countries for the Social Progress Index with corresponding WCGI values in 2016 [2,4]

\begin{tabular}{|l|l|l|l|}
\hline № & \multicolumn{1}{|c|}{ Country } & Mark of the SPI & Group at WCGI \\
\hline 1 & Finland & 90.09 & Group 2 \\
\hline 2 & Canada & 89.49 & Group 1 \\
\hline 3 & Denmark & 89.39 & Group 1 \\
\hline 4 & Australia & 89.13 & Group 2 \\
\hline 5 & Switzerland & 88.87 & Group 1 \\
\hline 6 & Sweden & 88.80 & Group 1 \\
\hline 7 & Norway & 88.70 & Group 1 \\
\hline 8 & Netherlands & 88.65 & Group 2 \\
\hline 9 & UK & 88.58 & Group 1 \\
\hline 10 & Iceland & 88.45 & Group 2 \\
\hline 11 & New Zealand & 88.45 & Group 2 \\
\hline 12 & Ireland & 87.94 & Group 2 \\
\hline 13 & Austria & 86.60 & Group 1 \\
\hline 14 & Japan & 86.54 & Group 1 \\
\hline 15 & Germany & 86.42 & Group 1 \\
\hline 16 & Belgium & 86.19 & Group 1 \\
\hline 17 & Spain & 85.88 & Group 2 \\
\hline 18 & France & 84.79 & Group 1 \\
\hline 19 & the United States & 84.62 & Group 1 \\
\hline
\end{tabular}

The determination of the dependent and influential data array was made taking into account:

- a time lag present in the processes of formation both of corporate governance and of the processes of social standards development on a country-wide scale;

- peculiarities of calculating the above indicators (complexity and frequency - once a year).

A cross-correlation between the data of both indices in 2016 and 2017 was calculated to determine dependent and influential data arrays. The results of calculations are presented in Table 3.

Table 3: Cross-correlation matrix of the Social Progress Index with the World Corporate Governance Index in 2016 and 2017 [2,3,4,5]

\begin{tabular}{|c|c|c|c|}
\hline & SPI 2016 & SPI 2017 & \\
\hline WCGI 2016 & 0.8278 & 0.8943 & WCGI 2016 \\
\hline WCGI 2017 & 0.7591 & 0.8452 & WCGI 2017 \\
\hline
\end{tabular}

It should be noted that the correlation coefficient between the values of WCGI (2017) and SPI (2016) is almost 76\%, while this indicator is lower than in the cases of pair correlations in 2016 and 2017, respectively. However, the correlation coefficient is the highest between the values of WCGI (2016) and SPI (2017) at almost $89.5 \%$, which is the highest indicator of all calculations received. 
Based on this, it can be concluded that the Social Progress Index is the dependent indicator, and the World Corporate Governance Index is the influential one. This statement fully confirms the hypothesis of Wan Fauziah and Idris Adamu.

Relying on the research of Wan Fauziah and Idris Adam and based on the above, it was discovered that the corporate sector is a trend-forming system, i.e. the response of corporations around the world to phenomena or processes can be extrapolated to the reaction of society in which they operate. Evasion of the corporate sector from the enforcement of legislation, fraud, the use of cheaper raw materials, evasion of punishment, the use of outdated equipment and other negative examples suggest to other companies that such functioning is possible at the level of corporations, and therefore at their level too. As a result, it forms deviations in people's everyday life. Conversely, innovative activity, corporate social responsibility, charity, and unshadowing show a positive example to others and set a tendency for the development of society in these areas. The use of indicators such as SROI by large companies shapes trends for their use at the level of small and medium businesses and teaches people at the household level to link their well-being not only to the level of financial wealth and the ability to ensure their basic needs but also with the level of development in the society in which the individual lives. This prompts people to take initiative to introduce social innovation, which is becoming more relevant for Ukraine in the conditions of decentralization.

The scheme of influence vectors is presented in Figure 3.

Vectors $\mathbf{A}$ and $\mathbf{B}$ reflect the primary influence which can be attributed to any phenomena, changes or processes occurring in the external environment or declared by enterprises in relation to society (working conditions, salary levels, social package, etc.).

Ac is a vector that reflects the response of the corporate sector to the environmental impact (refusal or agreement with new tax rules, legislative and environmental standards, political fluctuations, etc.). At the same time, this vector has an indirect effect on society, partially adjusting its real attitude to the same phenomenon.

As is the response of society to the influence of the environment, which is formed from the real attitude of the society to the influence, adjusted for the reaction of the corporate sector to the said influence and the direct impact of the corporate sector on society.

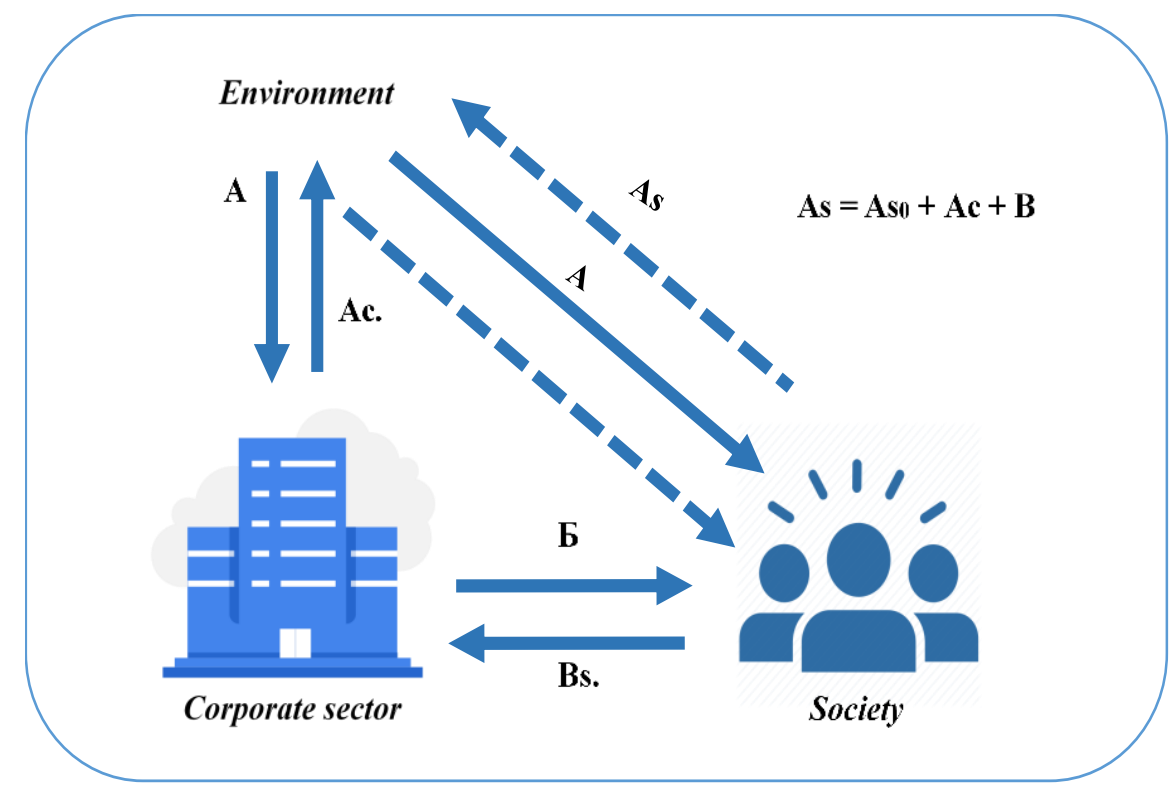

Fig. 3: Mechanism of influence of the corporate sector on the state of social standards

Thus, the previously presented correlation mechanism confirms that countries with high-level corporate governance show higher and stable indicators of social progress, among which are:

- basic human needs (medical care, decent living conditions, adequate nutrition);

- $\quad$ average life expectancy of over 65-70 years;

- access to education and technology;

- protection of human rights;

- fair wages:

- freedom of choice;

- general social responsibility of society, companies and individuals [2].

Social progress demonstrates the development of society in the context of increasing material and cultural level of the population and the creation of better conditions for human development and humanization of production.

The assessment of the dynamics of social standards and living standards is rather complicated, but for their characteristics, commonly used key indicators of social development, such as GDP per capita. Some corporations and their employees can make a rather significant contribution to the GDP of the country, for example, the share of PJSC Ukrzaliznytsia in the GDP of Ukraine is about 3\% [6].

Also, indicators of social change in society include the Human Development Index (HDI), which is based on life expectancy, education levels and GDP. According to this indicator, the world leaders are Norway, Australia and Switzerland [7].

According to various world organizations that are exploring the social, economic and environmental changes in the world (World Bank, UN, WHO, ILO, etc.), dynamics of the quantity and qualitative composition of the planet's population, its life expectancy, education level, level of poverty, food safety of the population, access to water resources, level of morbidity, state of the environment require regular assessment and monitoring (Figure 4). And a lot of world corporations have a significant impact on these indicators in different countries.

Corporate Social Responsibility (CSR) is one element of the impact system of corporations on the social environment and social standards formation in society. Its key principles and results are transmitted to society through social communication systems, and with the governmental support, they are transformed into an almost indispensable elements of effective social development of the country.

It should be noted that the social standards development through corporate influence has certain benefits for all system participants or stakeholders. 


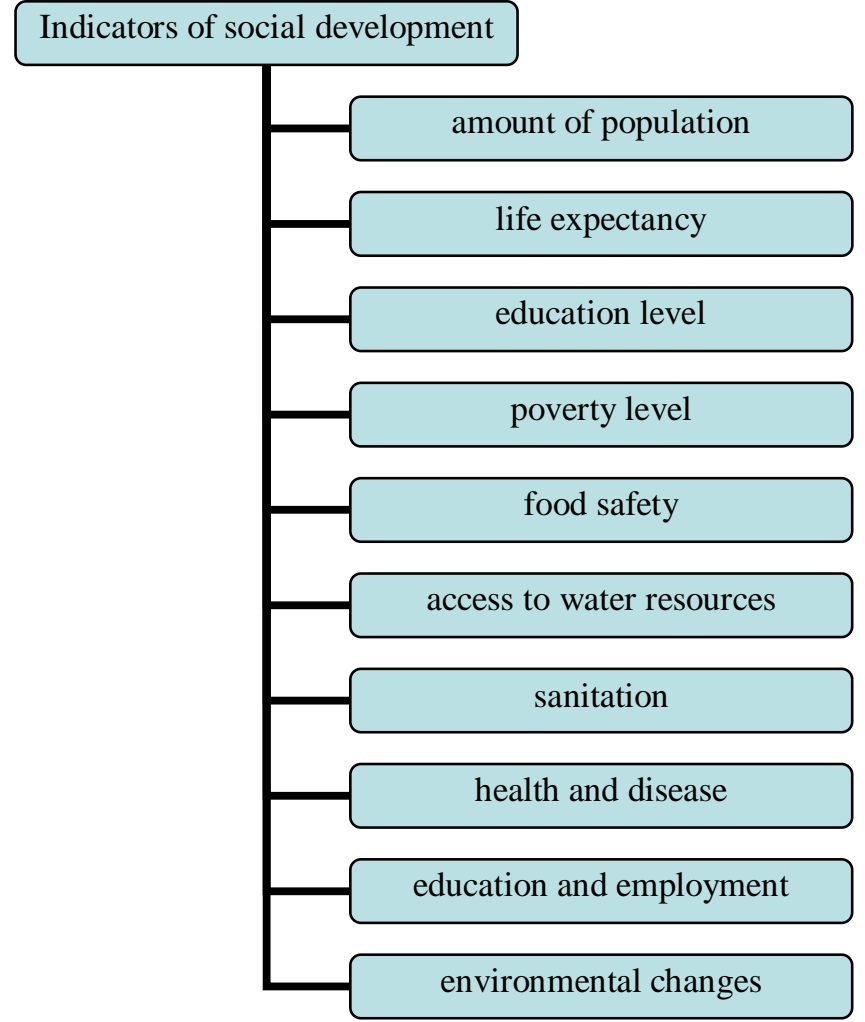

Fig. 4: Indicators of social, economic and environmental changes in the world [7].

Each of the parties can get a number of benefits that will stimulate stakeholders to further cooperation (Table 4). Because without the complex interaction of corporations, government and society, it will be difficult to achieve the necessary level of social development.

Table 4: Advantages of social standards development

\begin{tabular}{|c|c|c|}
\hline $\begin{array}{c}\text { For the corporate } \\
\text { sector }\end{array}$ & For the society & For the state \\
\hline $\begin{array}{l}\text { - growth of social } \\
\text { effect from activity; } \\
\text { - innovative activity; } \\
\text { - expansion of access } \\
\text { to capital and mar- } \\
\text { kets through the } \\
\text { formation of a posi- } \\
\text { tive image; } \\
\text { - high efficiency of } \\
\text { employees; } \\
\text { - compliance with } \\
\text { quality standards; } \\
\text { - state support; } \\
\text { - a solid reputation; } \\
\text { - customer loyalty, } \\
\text { etc. }\end{array}$ & $\begin{array}{l}\text { - improving of living } \\
\text { standards; } \\
\text { - competitive wages; } \\
\text { - fair working condi- } \\
\text { tions; } \\
\text { - development of } \\
\text { health care; } \\
\text { - access to education; } \\
\text { - life and health insur- } \\
\text { ance; } \\
\text { - ecological safety; } \\
\text { - access to technolo- } \\
\text { gy; } \\
\text { - freedom of choice; } \\
\text { - formation of a so- } \\
\text { cially responsible } \\
\text { society as a whole. }\end{array}$ & $\begin{array}{l}\text { - development of pub- } \\
\text { lic-private partnership; } \\
\text { - support of the inte- } \\
\text { grated strategies im- } \\
\text { plementation for socio- } \\
\text { economic development; } \\
\text { - access to technology; } \\
\text { - support for European } \\
\text { integration initiatives; } \\
\text { - lowering the pressure } \\
\text { on the state in the } \\
\text { sphere of providing part } \\
\text { of social standards for } \\
\text { the population (medical } \\
\text { insurance, pensions, } \\
\text { etc.) }\end{array}$ \\
\hline
\end{tabular}

Measures for the implementation of social investments by large corporations can reduce the pressure on the state in the area of providing certain social standards for the population. For example, large companies practice the creation of their own pension funds, the provision their employees with housing, health insurance or life insurance, guarantee a certain level of wages, etc. (Royal Dutch Shell, Exxon Mobil, Apple, Walmart, Nestle, Ford Motor, etc.). Thus, the development of the corporate sector stimulates an increase in social standards at the macro level, which is especially relevant for Ukraine.

Both private and state corporations can make an impact on the social standards formation. PJSC Ukrzaliznytsia is an example of a large state corporation, whose actions may contribute to changes in social standards. This is a state-owned company which holds a monopoly on rail passenger and cargo transportation in Ukraine. In addition, the total share of the company in the Ukrainian trans- portation market is $82 \%$ of freight and almost $50 \%$ of passenger traffic carried by all modes of transport. In terms of freight traffic, the Ukrainian railroad is ranked fourth in the Eurasian continent, following only the railways of China, Russia and India [6].

As a result of the analysis of company performance indicators and priorities for its strategic development, several key areas of company impact on social development indicators and social standards in Ukraine can be distinguished (Figure 5).

national transport corporation - $82 \%$ of freight and almost $50 \%$ of passenger traffic - implementation of the freedom of movement principle

more than 200 thousand jobs - the largest employer of Ukraine (1.5\% of all employed)

health insurance and treatment of workers (departmental health care institutions) - support of health standards among employees

social programs (household fuel and children rest)

education and science (support for specialized educational institutions and research institutes)

access to transport infrastructure for population and business

town-creating enterprise in many regions

Fig. 5: Example of PJSC Ukrzaliznytsya influence on the formation of social standards / social development in Ukraine.

So, the corporation is one of the leaders in creating jobs and is focused on ensuring the workers' social needs (treatment, rest, training, insurance, accommodation); it also provides the population with access to passenger and freight transportation at competitive prices. In accordance with the actions of state and private corporations, social standards are gradually increasing at smaller enterprises, and the state social minimum is changing in response to the needs (demands) of society.

\section{Conclusion}

The results of investigating mutual influence of the corporate governance development level and social progress level in different world countries confirm the correlation between high level of corporate governance and higher and more stable indicators of social progress.

Thus, the established mechanism can be used for the development of social standards in Ukraine, for raising the standard of living and economic growth through:

1. Strengthening the interaction of universities and NGOs with business in the following areas:

- development and implementation of CSR;

- building corporate culture;

- energy and resource efficiency;

- green technology;

2. Strengthening state control over large enterprises to form the following trends:

- compliance with tax legislation;

- compliance with environmental legislation;

- compliance with labor laws, etc. 
3. Additional advocacy for socially responsible behavior through:

- requirements for marking and packaging;

- control and requirements for disclosure and protection of information;

- disclosure of court decisions against large companies and so on.

The above statements are relevant to Ukraine as for a state with a very large number of problems both at the national level and at the level of individual enterprises and households. Solving these problems at the level of the corporate sector will make it possible to solve them at all other levels by creating models, setting trends, demonstrating examples, credibility, etc.

\section{References}

[1] Wan Fauziah, Idris Adamu, Insight of Corporate Governance Theories, Journal of Business \& Management, Published by Science and Education Centre of North America (2012) 52 - 63.

[2] Social Progress Index 2016, available online: http://www.socialprogressimperative.org/wpcontent/uploads/2016/06/SPI-2016-Main-Report.pdf. Revised June, 2016. Accessed June 17, 2018.

[3] Social Progress Index 2017, available online: https://www.socialprogressindex.com/assets/downloads/resources/e n/English-2017-Social-Progress-Index-Findings-Report_embargod-until-June-21-2017.pdf. Revised June 21, 2017. Accessed June 17 2018.

[4] World Corporate Governance Index Report 2016, available online: http://www.doganholding.com.tr/_files/en/ratingreport/rating_report_2016.pdf. Revised 2016. Accessed June 17 , 2018.

[5] World Corporate Governance Index Report 2017, available online: http://www.saharating.com/ saharati/en/wpcontent/uploads/2017/07/2017-Report-CORPORATEGOVERNANCE-INDEX-2017.pdf. Revised 2017. Accessed June $17,2018$.

[6] The main aspects of the Development Strategy of PJSC "Ukrzaliznytsya" for 2017-2021, available online: https://www.uz.gov.ua/files/file/Strategy_Presentation_fin1.pdf. Revised 2017. Accessed June 17, 2018.

[7] Center for Sustainable Systems University of Michigan. Social Development Indicators, available online: http://css.umich.edu/sites/default/files/css_doc/CSS08-15.pdf. Revised August, 2016. Accessed June 17, 2018. 